\title{
Role of C-Peptide in Relation to Levels of Anti-GAD and Islet Cell Antibodies in Characterizing Types of Diabetes in the Young, in Eastern India
}

\author{
Sidhartha Das' ${ }^{1}$ Dipanweeta Routray², Manoranjan Behera ${ }^{3}$, Saroj Kumar Tripathy ${ }^{4}$ \\ ${ }^{1}$ Formerly, HOD P. G. Department of Medicine and Dean and Principal, SCBMCH, Cuttack, India \\ ${ }^{2}$ Department of Community Medicine, SCBMCH, Cuttack, India \\ ${ }^{3} \mathrm{SCBMCH}$, Cuttack, India \\ ${ }^{4}$ Department of Department of Medicine. S. L. M. Medical College, Koraput, Odisha, India \\ Email: drsidhartha.cuttack@gmail.com,drdipanweeta@gmail.com,doctor_manoranjan@rediffmail.com, sarojtripathyl@hotmail.com
}

How to cite this paper: Das, S., Routray, D., Behera, M. and Tripathy, S.K. (2022) Role of C-Peptide in Relation to Levels of Anti-GAD and Islet Cell Antibodies in Characterizing Types of Diabetes in the Young, in Eastern India. Journal of Diabetes Mellitus, 12, 1-11.

https://doi.org/10.4236/jdm.2022.121001

Received: October 23, 2021

Accepted: November 27, 2021

Published: November 30, 2021

Copyright $\odot 2022$ by author(s) and Scientific Research Publishing Inc. This work is licensed under the Creative Commons Attribution International License (CC BY 4.0).

http://creativecommons.org/licenses/by/4.0/

(c) (i) Open Access

\begin{abstract}
Background: Measuring fasting C-peptide (FCP) and antibodies against Glutamic acid decarboxylase (GADA) and Islet cell antibodies (ICA) are not so commonly explored in children and young adults. Objectives: To assess the levels of FCP, GADA and ICA in subjects below the age of 25 years with DM and compare their levels to differentiate between Autoimmune and Non-Autoimmune Type 1 DM. Methodology: Blood samples of 93 subjects diagnosed with $\mathrm{DM}$, reporting to the tertiary care hospital, were analysed for ICA, GADA and FCP. Receiver operating characteristics (ROC) curves were analysed to check the ability of autoimmune markers, BMI and C-peptide to differentiate between Autoimmune (Ai) and Non-Autoimmune (NonAi) diabetes. Results: 30/93 (32.2\%) were positive for anti-GAD ab and/or ICA and categorised as Autoimmune (Ai), the most common antibody being, anti-GAD ab (80\%) in them. The level of FCP among Ai compared to NonAi, was significantly low $(\mathrm{p}<0.001)$. The combined effect of Age and BMI on the level of FCP was lesser in autoimmune diabetes. Receiver Operating Characteristic Curve ROC analysis demonstrated the advantage of raised GAD ab ( $>20.75 \mathrm{nmol} / \mathrm{l})$ as a very dependable test for diagnosing Ai, Type $1 \mathrm{DM}$, in children and young adults. Its sensitivity and specificity are in the range of $86.2 \%$ and $96.8 \%$ respectively. Low level of C-peptide $(<0.36 \mathrm{nmol} / \mathrm{l})$ is a fair indicator for diagnosing Ai diabetes in the same population unlike BMI. Conclusion: This study revealed predominant positivity for anti-GAD ab (80\%) among Ai+ patients. ROC analysis shows GADA above $20.75 \mathrm{nmol} / \mathrm{l}$ and Fasting C-peptide $<0.36 \mathrm{nmol} / \mathrm{l}$ as a good indicator for diagnosing $\mathrm{Ai}$ in children and young adults.
\end{abstract}




\section{Keywords}

C-Peptide, Anti-Glutamic Acid Decarboxylase Antibodies (GADA), Islet Cell Antibodies (ICA), ROC Analysis, Type 1 DM, Type 2 DM

\section{Introduction}

Diabetes mellitus (DM) is a metabolic disorder characterized by chronic hyperglycaemia consequent to defects in Insulin secretion, action or both. The etiopathogenic mechanisms behind developing chronic hyperglycaemia are not common to all [1]. As revealed by ICMR INDIAB study, 62.4 million people are living with diabetes and 77.2 million with prediabetes in India [2]. In the global scenario, Type 1 diabetes mellitus (T1DM) is considered the most common form of diabetes seen in youth, so also the most prevalent type of DM seen in children and adolescents.

In India, prevalence of T1DM is lesser than in Europe and North America. Reviews have shown that there are three new cases of T1DM/100,000 children of 0 - 14 years [3]. Besides, the prevalence data of T1DM from different parts of India is not uniform. Data on prevalence of Type $1 \mathrm{DM}$ showed that it was 17.93 cases/100,000 children in Karnataka, 3.2 cases/100,000 children in Chennai, and 10.2 cases/100,000 children in Karnal (Haryana) [3]. However, Type 2 diabetes mellitus (T2DM), often considered to be the type of DM of middle age or elderly, is increasingly being diagnosed among young adults and now also in adolescence and childhood due to burgeoning epidemic of childhood obesity and strong family history of Type $2 \mathrm{DM}$. The most prevalent forms of DM diagnosed in paediatric age group are Type $1 \mathrm{DM}$, followed by youth onset Type 2 Diabetes (T2DM). Other types of DM such as latent autoimmune diabetes of adult (LADA), Maturity onset diabetes in young (MODY), Gestational DM (GDM), fibro calculous pancreatic diabetes (FCPD) are also seen in persons less than 25 years of age [4].

Type $1 \mathrm{DM}$ is mostly due to autoimmune destruction of Islet $\beta$ cells at early stage of life [1]. T1DM children need insulin therapy for survival from a very early stage, require much more medical dedicated care and are susceptible to microvascular complications earlier than those who belong to other types of DM [5]. Diagnosis of T1DM can be fairly made by detecting anti-GAD65ab and antibodies against Islet cell (Anti IA12ab) in blood [3].

Islet $\beta$ cells activity and reserve for insulin can be assessed by analysing circulating levels of connecting peptide (C-Peptide) in blood. C-peptide is the part of proinsulin which is cleaved prior to co-secretion with insulin from pancreatic beta cells. It being metabolically inert, is widely used to measure pancreatic $\beta$ cell function [6]. The role of C-peptide in the diagnosis of diabetes is currently limited to unusual or ambiguous cases of Type 1 or Type 2 DM [7]. Classification of DM is often difficult in younger adults and more so in children [4] [8]. The 
recommendations proposed classification on aetiological grounds into mainly autoimmune, or Type 1, and non-autoimmune, or Type 2, diabetes [9]. The importance of level of $\beta$ cell function, measured as C-peptide, is well recognised in autoimmune diabetes [10]. Also in non-autoimmune diabetes, interest in $\beta$ cell function has recently risen considerably [11].

\section{Objectives}

The aim of this study was to assess the levels of C-peptide, and their relations to age and levels of circulating antibodies against $\beta$ cells (anti-GAD $\mathrm{Ab}$ and Islet cell $\mathrm{Ab}$ ), in children and young adults with newly diagnosed DM and also to explore the usefulness of C-peptide levels, BMI and age in classification of diabetes at diagnosis in the children and young patients.

\section{Methodology}

Our study was cross-sectional study conducted in the Post Graduate Department of Medicine of S.C.B. Medical College and Hospital, Odisha between January 2017 to January 2019.

\subsection{Subjects}

In total, 93 consecutive newly diagnosed patients with DM as per WHO criteria in different wards and clinics with age at the onset of diabetes between 0 to 25 years attending, admitted and under care of consultants attached to Department of Medicine, Endocrinology and Paediatrics were enrolled for the study. The study was conducted in a specialised centre for the purpose in the Department of Medicine. The population was ethnically homogeneous with majority coming from the adjacent districts of Cuttack. The study was approved by the Ethics Committee of the Institution.

\subsection{Methods}

DM was diagnosed according to World Health Organisation (WHO) criteria [1].

Blood samples were collected at the time of diagnosis. Blood glucose was done by glucose oxidase method in venous blood. Glycosylated Hemoglobin (Hb A1c) estimation was done by ion exchange chromatography method. All the selected patients were evaluated for the presence of Islet cell antibody (ICA), Glutamic acid decarboxylase antibody (anti-GADab) and fasting C-peptide (FCP). C-peptide was analysed by chemiluminescence by COBAS E411, manufactured by Roche Diagnostics, Germany and marketed in India by Roche Diagnostics Private Limited and kits manufactured by Roche Diagnostics, Germany.

ICA levels were analysed by ESILA, Instrument-BIO-RAD IMARK, manufactured in Japan and marketed in India by Immunoshop Private Limited. Kits were manufactured by AESKU Diagnostics, Germany with a detection limit of 9 JDF-U, sensitivity $100 \%$ and specificity $88 \%$; $<30.00 \mathrm{IU} / \mathrm{ml}$. Ant-GAD ab levels were analysed with radioimmunoprecipitation in the same machine as ICA. 
Both analyses were standardised according to the Diabetes Antibody Standardization Program.

The term autoimmune diabetes $(\mathrm{Ab}+)$ was used if subjects were positive to at least one of the antibodies to islet cells and/or glutamic acid decarboxylase. Those negative for both antibodies were designated nonautoimmune (Ab-).

Height and weight of young diabetes patients were measured by a nurse in the department. BMI $\left(\mathrm{kg} / \mathrm{m}^{2}\right)$ were calculated within each annual age category, and percentiles calculated according to Indian Academy of Paediatrics [12] for 5 - 18 years age group, and CDC [13] guidelines for 2 - 5 years age group and accordingly they were categorised as below normal, normal and above normal. Calculation of BMI was possible for $98 \%$ of the subjects.

Family history of diabetes in grandparents, parents and siblings were taken in all subjects.

The relationship between FCP and blood glucose level at the time of sampling for FCP was investigated.

\subsection{Statistical Analysis}

Descriptive statistics are reported in 5-year-age groups and five BMI groups. Differences between groups were explored by ANOVA/Kruskal Wallis Test wherever applicable, when appropriate with post hoc Bonferroni correction. The quantitative non-parametric data and parametric data were analysed using Mann-Whitney U and Student's t-test for independent samples respectively. Receiver operating characteristics (ROC) curves were analysed to check the ability of age, BMI and C-peptide to differentiate between auto-antibody positive $(\mathrm{Ab}+)$ and negative $(\mathrm{Ab}-)$ diabetes. The data was analysed by SPSS version 25 . All tests were two tailed, and a significance level of 0.05 was considered significant.

\section{Results}

The study has enrolled 93 patients (32.2\% male; $67.8 \%$ female). There was no significant gender difference in the proportional distribution of diabetes categories. Out of the 93 patients, 30 (32.2\%) were positive for antibodies and nomenclature as Autoimmune ( $\mathrm{Ai}+$ ) and the rest as Non-Autoimmune (Non-Ai) respectively was done. The basic characteristics of the two groups are presented in Table 1. There was a significantly lower level of Fasting C-Peptide (FCP) among $\mathrm{A} i+$ compared to NonAi $(\mathrm{p}<0.001)$.

The markers of autoimmune destruction of islet $\beta$ cells i.e. presence of anti-GAD ab and ICA and levels in terms of median and Q1Q3 were significantly higher in Ai+ group [GADA: 95.8 (44.6 - 215.5); ICA: 9.5 (6.6 - 27.2)] as compared to NonAi group [GADA: 5.6 (2.4 - 8.13); ICA: 7.8 (4.6 - 10.8)] (P values $0.01,<0.001$ respectively).

The median age of Ai patients was significantly lower as compared to NonAi. Among the Non-Ai patients, 13/53 (20.63\%) had family history of Diabetes, which was significantly higher $(p<0.001)$ than Ai patients $1 / 30(3.3 \%)$. 
Table 1. Characteristics of the study subjects $(\mathrm{N}=93)$.

\begin{tabular}{|c|c|c|c|}
\hline Characteristics & $\begin{array}{l}\text { Autoimmune }(\mathrm{n}=30) \\
\quad(\text { Mean } \pm \text { SD })\end{array}$ & $\begin{array}{l}\text { Non-autoimmune }(63) \\
\quad(\text { Mean } \pm \text { SD) }\end{array}$ & P value \\
\hline $\begin{array}{l}\text { Age in months } \\
\qquad \text { Median (Q1 - Q3) }\end{array}$ & $\begin{array}{c}9.4 \pm 6.2 \\
9.0(0.66-25)\end{array}$ & $\begin{array}{c}15.7 \pm 6.8 \\
16(0.16-25)\end{array}$ & $<0.001^{*}$ \\
\hline BMI & $16.04 \pm 5.1$ & $17.7 \pm 5.8$ & 0.21 \\
\hline FBG & $242.4 \pm 96.2$ & $233 \pm 107.9$ & 0.68 \\
\hline PPBG & $327.07 \pm 128.5$ & $316 \pm 145.8$ & 0.73 \\
\hline $\mathrm{HbA1C}$ & $9.4 \pm 2.1$ & $9.7 \pm 3.7$ & 0.84 \\
\hline $\begin{array}{l}\text { C peptide (IU/ml) } \\
\quad \text { Median (Q1 - Q3) }\end{array}$ & $\begin{array}{c}0.36 \pm 0.35 \\
0.24(0.1-0.49)\end{array}$ & $\begin{array}{c}1.2 \pm 5.2 \\
0.83(0.4-1.7)\end{array}$ & $<0.001$ \\
\hline $\begin{array}{l}\text { Islet cell Ab (IU/ml) } \\
\qquad \text { Median (Q1 - Q3) }\end{array}$ & $\begin{array}{c}49.2 \pm 97.6 \\
9.5(6.6-27.2)\end{array}$ & $\begin{array}{c}8.3 \pm 5.2 \\
7.8(4.6-10.8)\end{array}$ & $0.009^{*}$ \\
\hline $\begin{array}{l}\text { GADA }(\mathrm{IU} / \mathrm{ml}) \\
\quad \text { Median }(\mathrm{Q} 1 \text { - Q3) }\end{array}$ & $\begin{array}{c}211.72 \pm 400.41 \\
95.8(44.6-215.5)\end{array}$ & $\begin{array}{c}6.07 \pm 4.7 \\
5.6(2.4-8.13)\end{array}$ & $<0.001^{\star}$ \\
\hline $\begin{array}{c}\text { Family history } \\
\text { Positive } \\
\text { Negative }\end{array}$ & $\begin{array}{c}1(3.3) \\
29(96.7)\end{array}$ & $\begin{array}{l}13(20.63) \\
50(79.37)\end{array}$ & $0.029^{* *}$ \\
\hline $\begin{array}{l}\text { Gender } \\
\qquad \begin{array}{l}\text { Males } \\
\text { Females }\end{array}\end{array}$ & $\begin{array}{l}16(53.3) \\
14(46.7)\end{array}$ & $\begin{array}{l}31(49.2) \\
32(50.8)\end{array}$ & $(0.71)$ \\
\hline
\end{tabular}

${ }^{*}$ Independent Sample T test, ${ }^{\star}$ Mann-Whitney U test, ${ }^{* *}$ 2 (Chi square) test.

The other parameters like BMI, FBG, PPBG, HbA1C and duration of diabetes in months were comparable.

\subsection{C-Peptide}

The mean FCP was $0.94 \pm 1.19$ (range-0.01 - 8.28) nmol/l. Mean FCP was significantly lower in the newly diagnosed with Ai diabetes than that in the NonAi group (Table 2). There was no significant mean FCP difference with regard to gender in $\mathrm{Ab}+$ and $\mathrm{Ab}-$ groups.

Results showed that $24 / 30$ (80\%) were positive for anti-GADA ab, $4 / 30$ (13.3\%) for ICA and only $2 / 30(6.6 \%)$ were positive for both the antibodies. The mean FCP in only anti-GAD ab positive subjects, 0.33 range $0.01-1.00$, was lower than that in the NonAi, 1.21, range $0.01-8.28$, where the difference was significant. There were no significant differences in the levels of C-peptide between any of the $\mathrm{Ab}+$ groups.

The level of FCP increased significantly with age at diagnosis in both Ai and Non-Ai new diabetes cases (both $\mathrm{P}<0.001$ ). For every 1 -year increase in age in the newly diagnosed, FCP was $0.05 \mathrm{nmol} / \mathrm{l}$ higher in Ai and $0.02 \mathrm{nmol} / \mathrm{l}$ higher in NonAi cases. However, the positive strong correlation between FCP and age was apparent upto 0 - 10 years in $\mathrm{Ai}+$ group, and 16 - 25 age group in $\mathrm{Ai}$ - group (Figure 1). 
Table 2. Fasting C-peptide levels (unit), and BMI $\left(\mathrm{Kg} / \mathrm{m}^{2}\right)$, per age group in children and young adults with newly diagnosed diabetes. Values are Mean \pm S.D; median, Min-Max.

\begin{tabular}{|c|c|c|c|c|c|c|c|c|c|c|}
\hline \multicolumn{6}{|c|}{ C-peptide } & \multicolumn{5}{|c|}{ BMI } \\
\hline $\begin{array}{c}\text { Age } \\
\text { (Years) }\end{array}$ & $\mathrm{N}$ & Autoimmune & $\mathrm{N}$ & Non-Autoimmune & $\begin{array}{l}\mathrm{P}, \mathrm{Ai} \text { vs } \\
\text { Non-Ai }\end{array}$ & $\mathrm{n}$ & Autoimmune & $\mathrm{n}$ & Non-Autoimmune & $\begin{array}{l}\mathrm{P}, \mathrm{Ai} \text { vs } \\
\text { Non-Ai }\end{array}$ \\
\hline $0-5$ & 08 & $\begin{array}{c}0.25 \pm 0.19 \\
0.25(0.01-0.58)\end{array}$ & 04 & $\begin{array}{c}0.23 \pm 0.11 \\
0.23(0.1-0.36)\end{array}$ & 1 & 04 & $\begin{array}{c}13.55 \pm 1.42 \\
13.6(12-15)\end{array}$ & 02 & $\begin{array}{c}14.6 \pm 0.56 \\
14.6(14-15)\end{array}$ & 0.393 \\
\hline $6-10$ & 13 & $\begin{array}{c}0.30 \pm 0.29 \\
0.21(0.01-0.58)\end{array}$ & 12 & $\begin{array}{c}0.56 \pm 0.55 \\
0.42(0.01-1.95)\end{array}$ & 0.347 & 13 & $\begin{array}{c}14.3 \pm 3.0 \\
14.4(9-20)\end{array}$ & 12 & $\begin{array}{c}12.63 \pm 2.1 \\
12.5(9-17)\end{array}$ & 0.113 \\
\hline $11-15$ & 05 & $\begin{array}{c}0.25 \pm 0.34 \\
0.12(0.01-0.87)\end{array}$ & 15 & $\begin{array}{c}1.69 \pm 2.01 \\
1.02(0.42-8.28)\end{array}$ & 0.002 & 05 & $\begin{array}{c}21.1 \pm 8.8 \\
16.8(13-33)\end{array}$ & 15 & $\begin{array}{l}17.01 \pm 5.36 \\
14.3(12.32)\end{array}$ & 0.225 \\
\hline $16-20$ & 01 & 0.25 & 12 & $\begin{array}{c}1.23 \pm 0.91 \\
0.91(0.32-3.34)\end{array}$ & 0.154 & 01 & 15.2 & 12 & $\begin{array}{c}17.57 \pm 6.5 \\
14.3(12.32)\end{array}$ & 0.735 \\
\hline $21-25$ & 03 & $\begin{array}{c}1.08 \pm 0.34 \\
1(0.78-1.46)\end{array}$ & 20 & $\begin{array}{c}1.43 \pm 1.27 \\
0.91(0.41-4.3)\end{array}$ & 0.898 & 03 & $\begin{array}{c}18.53 \pm 4.47 \\
16.1(16-24)\end{array}$ & 20 & $\begin{array}{c}21.67 \pm 5.01 \\
21.1(15-34)\end{array}$ & 0.319 \\
\hline All & 30 & $\begin{array}{c}0.36 \pm 0.35 \\
0.24(0.01-1.46)\end{array}$ & 63 & $\begin{array}{c}1.2 \pm 1.3 \\
0.83(0.01-8.28)\end{array}$ & 0.001 & 26 & $\begin{array}{c}16.04 \pm 5.19 \\
15.2(9.4-33.8)\end{array}$ & 61 & $\begin{array}{c}17.7 \pm 5.84 \\
15.2(8.8-34.10)\end{array}$ & 0.213 \\
\hline
\end{tabular}

Ai, autoimmune; non-Ai, non-autoimmune ${ }^{\star} \mathrm{p}$ value by Mann-Whitney $\mathrm{U}$ test; \# $\mathrm{p}$ value by Student t-test.

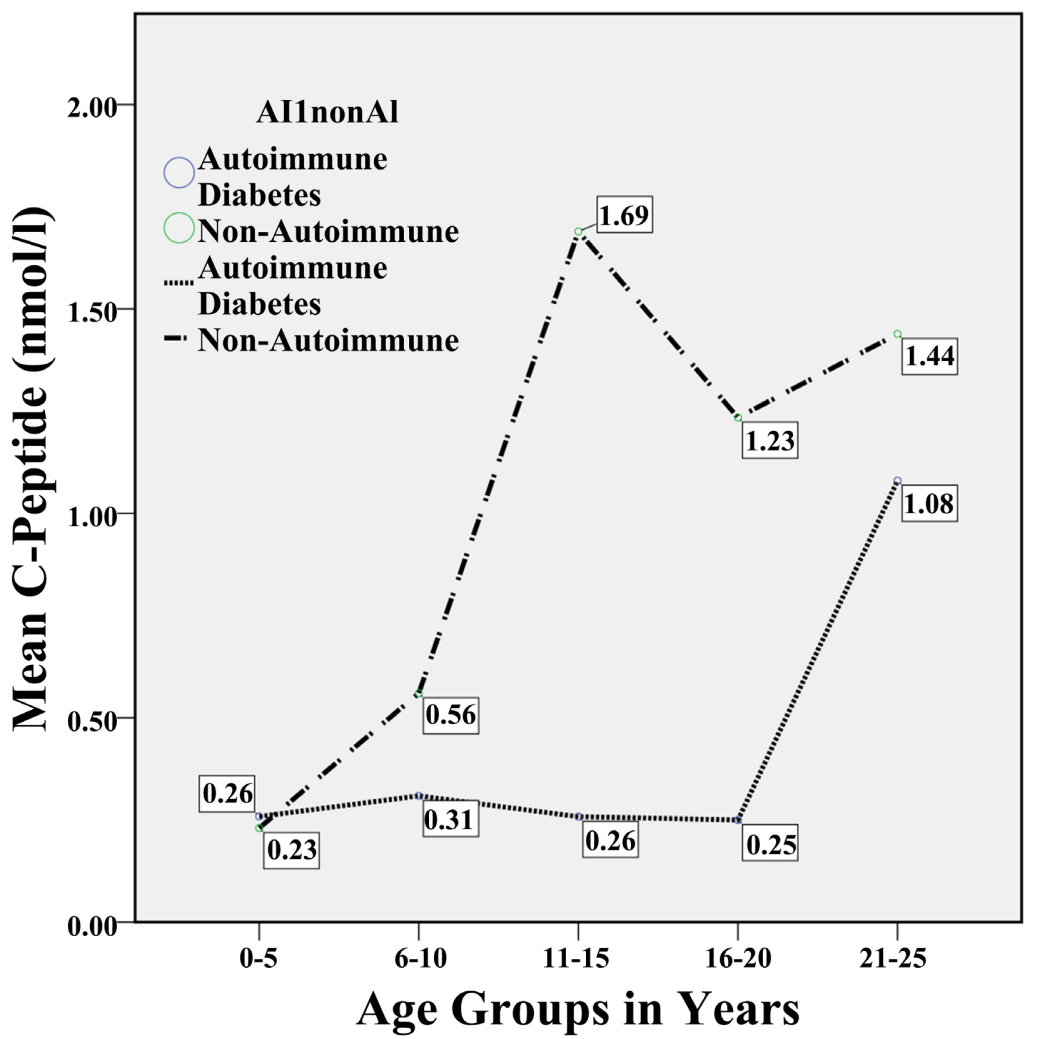

Figure 1. Mean fasting C-peptide (nmol/l), per age group per types of diabetes in children.

Level of FCP at onset of diabetes was independently influenced by both age and BMI. Their combined influence on the level of FCP was lesser in autoim- 
mune diabetes: 26\% (R2 0.268) when compared with 49\% (R2 0.499) in non-autoimmune diabetes ( $\mathrm{P}$ value $<0.05$ for both). FCP was $0.29 \mathrm{nmol} / 1$ higher per $1 \mathrm{~kg} / \mathrm{m}^{2}$ higher BMI in autoimmune and $0.66 \mathrm{nmol} / \mathrm{l}$ higher in NonAi, diabetes $(\mathrm{P}<0.05$ for NonAi). Mean FCP was correlated to increasing BMI, and $\mathrm{BMI}$ group, and to increasing age, also within each BMI group, and this was especially apparent in Ai diabetes.

\subsection{Body Mass Index (BMI)}

Mean BMI for all was $17.2 \pm 5.68$ (range $8.8-34.1$ ) $\mathrm{kg} / \mathrm{m}^{2}$. Mean BMI for the $\mathrm{Ab}+$ was $16.04 \pm 5.19$, which was lower than for the $\mathrm{Ab}-17.7 \pm 5.84$ but there was no statistical significance $(\mathrm{P}=0.213)$. This study did not show any change of BMI with antibody status $\mathrm{H}(2)=1.9, \mathrm{P}=5.7$ by Kruskal Wallis test (Table 2). Further analysis of C-peptide levels after stratification in three different BMI categories it is found that the C-peptide levels are consistently high in the NonAi group across all the BMI categories (Table 3 ).

\subsection{Receiver Operating Characteristic Curve (ROC) Analysis}

ROC curves for the subjects are displayed in Figure 2. AUC for GADA was superior to those for C-Peptide, ICA and BMI for differentiating between $\mathrm{Ai}$ and Non-Ai subjects. The AUC was 0.955 (0.901 - 1.00) for GADA, 0.785 (0.683 $0.887)$ for C-peptide, $0.700(0.579-0.821)$ for ICA and $0.451(0.320-0.581)$ for $\mathrm{BMI}$ in Ai patients.

The sensitivity and specificity of GADA at a cut-off of $>20.75 \mathrm{nmol} / \mathrm{l}$ are 86.2\% and $96.8 \%$ respectively is the most appropriate cut offs for diagnosing Ai in the region as the Youden's Index is maximum at these levels. The values for that of C-peptide at a cut off of $<0.36 \mathrm{nmol} / \mathrm{l}$ are $66.7 \%$ and $79.4 \%$ respectively, (Youden's Index $=0.461$ ) and seems to be the most appropriate cut offs for diagnosing Ai (Table 4).

Table 3. Fasting C-peptide levels (unit), per BMI group $\left(\mathrm{Kg} / \mathrm{M}^{2}\right)$ in children and young adults with newly diagnosed diabetes. Values are Mean \pm S.D; Median, Min-Max.

\begin{tabular}{cccccc}
\hline \multicolumn{5}{c}{ C-peptide } \\
\hline BMI Group & $\mathrm{N}$ & Autoimmune & $\mathrm{N}$ & Non-Autoimmune & $\begin{array}{c}\text { P, Ai vs } \\
\text { Non-Ai }\end{array}$ \\
\hline Below normal & 10 & $\begin{array}{c}0.38 \pm 0.47 \\
0.2(0.01-1.46)\end{array}$ & 22 & $\begin{array}{c}0.67 \pm 0.49 \\
0.6(0.06-1.89)\end{array}$ & 0.05 \\
\hline Normal & 14 & $0.36 \pm 0.29$ & 32 & $1.02 \pm 0.79$ & 0.001 \\
& & $0.26(0.01-0.93)$ & & $0.84(0.01-0.48)$ & \\
\hline Above normal & 2 & $0.53 \pm 0.47$ & 7 & $4.0 \pm 1.9$ & 0.056 \\
& & $0.53(0.2-0.87)$ & & $4.04(2.4-8.2)$ & \\
\hline All & 30 & $0.36 \pm 0.35$ & 63 & $1.2 \pm 1.3$ & $<0.001$ \\
& & $0.24(0.01-1.46)$ & & $0.83(0.01-8.28)$ & \\
\hline
\end{tabular}

$\mathrm{P}$ value by Mann Whitney $\mathrm{U}$ test. 
Table 4. ROC analysis of GADA, ICA and BMI for subjects who are autoimmune diabetes.

\begin{tabular}{cccc}
\hline Fasting C-Peptide (nmol/l) & Sensitivity (\%) & Specificity (\%) & YOUDEN’S INDEX \\
\hline 0.250 & 0.500 & 0.873 & $(\mathrm{Sn}+\mathrm{Sp})^{-1}$ \\
0.285 & 0.600 & 0.841 & 0.373 \\
0.310 & 0.600 & 0.825 & 0.441 \\
0.340 & 0.633 & 0.825 & 0.425 \\
0.368 & 0.633 & 0.810 & 0.458 \\
0.383 & 0.667 & 0.794 & 0.443 \\
GADA & & & 0.724 \\
8.15 & 0.966 & 0.758 & 0 \\
9.05 & 0.129 & 0.871 & 0.816 \\
10.55 & 0.897 & 0.919 & 0.797 \\
15.60 & 0.862 & 0.935 & 0.83 \\
20.75 & 0.862 & 0.968 & 0.828 \\
32.36 & 0.828 & 1.000 & \\
\hline
\end{tabular}

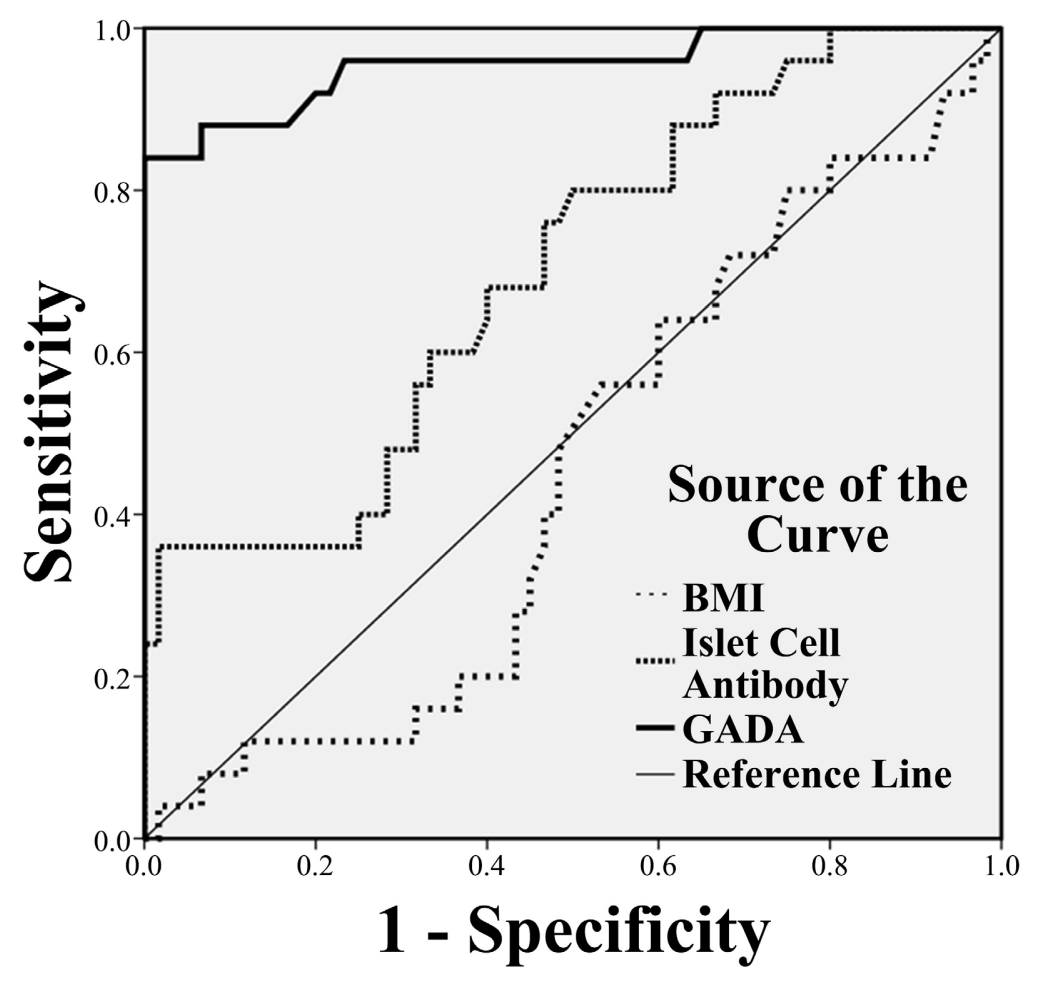

Figure 2. ROC analysis of GADA, ICA \& BMI to identify subjects who have autoimmune diabetes.

\section{Discussion}

The difference in the mean years of presentation between autoimmune and no-autoimmune diabetes is almost 6 years indicating that the latter probably are 
Type 2 DM at a very early age of onset. Even though childhood-obesity has been claimed to be one of the important causes of early onset of Type 2 DM in paediatric population, our study did not reveal higher BMI (obesity) to be an important determinant for type of diabetes. It is at par with the observations that South East Asian and especially Indians have different presentations with regards to DM [1].

The current study did not show significant difference between the mean values of FBG, PPBG, and HbAlc but the C-peptide values were significantly lower in Ai group suggesting fairly preserved b-cell activity in them. Thus, in our population the type of DM in the Non-Ai group with higher prevalence of family history could be due to substantially early age at onset of Type $2 \mathrm{DM}$.

The current study showed the overall magnitude of autoantibody positivity of $32 \%$ which is much higher (58.1\%) than previous studies conducted and reported in the Eastern part of India [14]. Our study showed a predominant positivity for anti-GAD ab (80\%) among $\mathrm{A} \mathbf{i}+$ patients and is comparable with the study by E Sabbah et al. from Finland [15]. Study by E Sabbah et al. had shown the prevalence of positive for anti-GAD Antibody at diagnosis to be $73.2 \%$ in children with DM. Presence of anti-GAD ab and particularly in higher titers predict diminishing beta cell function within the next few years following diagnosis of DM. In one of our earlier studies, presence of auto immune markers for islet $\beta$ cell damage in Type $2 \mathrm{DM}$, ideal body weight and lean body weight, prevalence of anti-GAD ab was absent in both categories while ICA was positive in 4 and 10 percent respectively [16]. Therefore, both our previous study and that of E Sabbah et al. are well corroborative of the fact that anti-GAD ab is a much better marker for autoimmune damage of islet $\beta$ cells. Another study conducted in children with positive standard islet autoantibodies found lower sensitivity (65\%) and specificity (68\%) of GADA to diagnose Type 1 DM. They found the accuracy by AUC in ROC to be lower for GADA in comparison to the present study [17].

The differences in frequency of $\mathrm{Ab}+$ between studies can be explained by the number and types of antibodies analyzed, duration of diabetes as well as ages in the populations studied. Patients testing negative for diabetes-associated autoantibodies at diagnosis seem to have a milder degree of beta-cell destruction. Interestingly, the higher FCP values in the age group of $21-25$ years in the $\mathrm{Ab}+$ group (Table 2 and Figure 1) suggest that they could be in honeymoon phase of Type1 DM or smouldering cases of LADA.

From the ROC analysis, our study demonstrates the utility of raised GADA ( $>20.75 \mathrm{nmol} / \mathrm{l})$ as a very dependable test for diagnosing Ai in children and young adults. Its sensitivity and specificity are in the $86.2 \%, 96.8 \%$ and are the most appropriate cut offs for diagnosing Ai respectively. Low level of C-peptide $(<0.36 \mathrm{nmol} / \mathrm{l})$ is a fair indicator for diagnosing Ai diabetes in the same population. Hence C-peptide below $0.36 \mathrm{nmol} / \mathrm{l}$ may be taken as a screening tool for diagnosing $\mathrm{Ai}$ in the same population. 
Raised ICA is a poor to fair indicator and BMI cannot be offered great credence as an indicator for diagnosing Ai Diabetes in children and young adults in our population. BMI was marginally lower in $\mathrm{Ai}+$ than those negative for antibodies. As they cross the age of 20, behave more akin to Type $2 \mathrm{DM}$.

This study is one of the first of its kind to estimate dual autoimmune markers in children and young adults in the eastern part of India. This may pave the path for correct categorization of type of DM at the earliest and hence timely management and prevention of complications of DM in this community.

\section{Conclusion}

The current study revealed higher prevalence of anti-GAD ab (80\%) positivity among Ai+ patients. Further, ROC analysis demonstrated the importance of raised values of anti-GAD ab (>20.75 nmol/l) as a very dependable parameter for diagnosing $\mathrm{Ai}$ in children and young adults. Its sensitivity and specificity were as high as $86.2 \%$ and $96.8 \%$ respectively. Even if ICA was positive in Ai group yet did not show much credence with regards to diagnosing Type $1 \mathrm{DM}$. Low level of C-peptide $(<0.36 \mathrm{nmol} / \mathrm{l})$ is a fair indicator for diagnosing Ai diabetes in the same population. However, BMI did not show any promise as an indicator for diagnosing the type of DM in children and young adults in our population. Studies with larger sample size may throw light on role of BMI and ICA in characterizing type of DM in children and young adults in India.

\section{Conflicts of Interest}

The authors declare no conflicts of interest regarding the publication of this paper.

\section{References}

[1] Powers, A.C. (2015) Diabetes Mellitus: Diagnosis, Classification and Pathophysiology. In: Kasper, D.L., Fauci, A.S., Hauser, S.L., Longo, D.L., Larry Jameson, J. and Loscalzo, J., Eds., Harrison's Principles of Internal Medicine, Vol. 2, 19th Edition, McGraw-Hill, New York, 2399-2407.

[2] Anjana, R.M., Pradeepa, R., Deepa, M., Datta, M., Sudha, V., Unnikrishnan, R., et al. (2011) Prevalence of Diabetes and Prediabetes (Impaired Fasting Glucose and/or Impaired Glucose Tolerance) in Urban and Rural India: Phase I Results of the Indian Council of Medical Research-India Diabetes (ICMR-INDIAB) Study. Diabetologia, 54, 3022-3027. https://doi.org/10.1007/s00125-011-2291-5

[3] Das, A.K. (2015) Type 1 Diabetes in India: Overall Insights. Indian Journal of Endocrinology and Metabolism, 19, S31-S33. https://doi.org/10.4103/2230-8210.155372

[4] Praveen, P.A., Madhu, V., Mohan, V., Das, S., Kakati, S., et al. (2016) Registry of Youth Onset Diabetes in India (YDR): Rationale, Recruitment, and Current Status. Journal of Diabetes Science and Technology, 10, 1034-1041. https://doi.org/10.1177/1932296816645121

[5] Powers, A.C. (2015) Diabetes Mellitus: Complications. In: Kasper, D.L., Fauci, A.S., Hauser, S.L., Longo, D.L., Larry Jameson, J. and Loscalzo, J., Eds., Harrison's Prin- 
ciples of Internal Medicine, Vol. 2, 19th Edition, McGraw-Hill, New York, 2422-2430.

[6] Leighton, E., Sainsbury, C.A.R. and Jones, G.C. (2017) A Practical Review of Peptide Testing in Diabetes. Diabetes Therapy, 8, 475-487.

https://doi.org/10.1007/s13300-017-0265-4

[7] Sacks, D.B., Arnold, M., Bakris, G.L., Bruns, D.E., Horvath, A.R., Kirkman, M.S., et al. (2011) Position Statement Executive Summary: Guidelines and Recommendations for Laboratory Analysis in the Diagnosis and Management of Diabetes Mellitus. Diabetes Care, 34, 1419-1423. https://doi.org/10.2337/dc11-9997

[8] Arnqvist, H.J., Littorin, B., Nystrom, L., Schersten, B., Ostman, J., Blohme, G., Lithner, F. and Wibell, L. (1993) Difficulties in Classifying Diabetes at Presentation in the Young Adult. Diabetic Medicine, 10, 606-613.

[9] Chan, J.C. and Ng, M.C. (2003) Lessons Learned from Young-Onset Diabetes in China. Current Diabetes Reports, 3, Article No. 101.

https://doi.org/10.1007/s11892-003-0032-y

[10] Thunande, M., Carina, T., Petersson, C., Ossiansson, B., Fornander, J., Landin-Olsson, M. (2012) Levels of C-Peptide, Body Mass Index and Age, and Their Usefulness in Classification of Diabetes in Relation to Autoimmunity, in Adults with Newly Diagnosed Diabetes in Kronoberg, Sweden. European Journal of Endocrinology, 166, 1021-1029. https://doi.org/10.1530/EJE-11-0797

[11] Marchetti, P., Lupi, R., Del Guerra, S., Bugliani, M., D’Aleo, V., Occhipinti, M., Boggi, U., Marselli, L. and Masini, M. (2009) Goals of Treatment for Type 2 Diabetes: Beta-Cell Preservation for Glycemic Control. Diabetes Care, 32, S178-S183. https://doi.org/10.2337/dc09-S306

[12] Khadilkar, V., Yadav, S., Agrawal, K.K., Tamboli, S., Banerjee, M., Cherian, A., et al. (2015) Revised IAP Growth Charts for Height, Weight and Body Mass Index for 5to 18-Year-Old Indian Children. Indian Pediatrics, 52, 47-55. https://doi.org/10.1007/s13312-015-0566-5

[13] CDC (Centers for Disease Control and Prevention) (n.d.) Using the BMI-for-Age Growth Charts.

https://www.cdc.gov/nccdphp/dnpa/growthcharts/training/modules/module1/text/ module1print.pdf

[14] Sanyal, D., Batabyal, S.K., Maity, S., Chatterjee, S. (2019) Changing Autoimmunity in Indian Type 1 Diabetes Children. Clinical Diabetology, 8, 116-120. https://doi.org/10.5603/DK.2019.0005

[15] Sabbah, E., Savola, K., Kulmala, P., Veijola, R., Vähäsalo, P., Karjalainen, J., et al. (1999) Diabetes-Associated Autoantibodies in Relation to Clinical Characteristics and Natural Course in Children with Newly Diagnosed Type 1 Diabetes. The Childhood Diabetes in Finland Study Group. Journal of Clinical Endocrinology \& Metabolism, 84, 1534-1539. https://doi.org/10.1210/jcem.84.5.5669

[16] Das, S., Bhoi, S.K., Baliarsinha, A.K. and Baig, M.M.A. (2007) Autoimmunity, Insulin Resistance and Betacell Function in Subjects with Low Bodyweight Type 2 Diabetes Mellitus. Metabolic Syndrome and Related Disorders, 5, 136-141. https://doi.org/10.1089/met.2006.0024

[17] Krischer, J.P., Liu, K., Vehik, K., Akolkar, B., Hagopian, W.A., Rewers, M.J., et al. (2019) Predicting Islet Cell Autoimmunity and Type 1 Diabetes: An 8-Year TEDDY Study Progress Report. Diabetes Care, 42, 1051-1060. https://doi.org/10.2337/dc18-2282 